\title{
Serosurvey of Toxoplasma gondii, Sarcocystis sp. and Neospora caninum in geese (Anser sp.) from urban parks and captivity
}

Soroprevalência de Toxoplasma gondii, Sarcocystis sp. e Neospora caninum em gansos (Anser sp.) de parques urbanos e cativeiro

Aline Luiza Konell1* (1); Ana Paula Sato ${ }^{1}$; Marina Stival²; Nathália Parreira Malaguini;

Alan dos Anjos ${ }^{3}$; Rafaela Furioso Ferreira ${ }^{4}$; Rosangela Locatelli-Dittrich ${ }^{1}$

\author{
${ }^{1}$ Programa de Pós-graduação em Ciências Veterinárias, Universidade Federal do Paraná - UFPR, Curitiba, PR, Brasil \\ ${ }^{2}$ Médica Veterinária Autônoma, Curitiba, PR, Brasil \\ ${ }^{3}$ Programa de Pós-graduação em Microbiologia, Parasitologia e Patologia, Universidade Federal do Paraná - UFPR, Curitiba, PR, \\ Brasil \\ ${ }^{4} \mathrm{PhD}$ Student at Faculty of Veterinary Medicine, University of Zagreb, Croatia
}

Received November 13, 2018

Accepted May 8, 2019

\begin{abstract}
Geese, ducks, mallards, and swans are birds of the order Anseriformes, which are found in the wild, in zoos and parks, and raised for meat consumption. Toxoplasma gondii, Sarcocystis sp., and Neospora caninum are protozoans of several species of animals. Wild and domestic birds can serve as intermediate hosts, disseminators and potential sources of infection of these protozoa to humans through contaminated meat. The aims of this study were: (i) to perform a serological survey of T. gondii, Sarcocystis sp. and N. caninum in geese (Anser sp.) from public parks and from captivity and (ii) to compare seroprevalence between these two locations. Antibodies were detected by Immunofluorescence antibody test using the serum of 149 geese. Antibodies to Sarcocystis sp., T. gondii, and N. caninum were detected in 28.18\%, $18 \%$ and $0.67 \%$ of geese, respectively; $57 \%$ of geese from urban parks and $26.53 \%$ of geese from captivity were seropositive for at least one protozoa. The results indicate environmental contamination, particularly for the occurrence of antibodies against T. gondii-a zoonosis that causes toxoplasmosis and is transmitted through oocyte ingestion. This is the first serological survey of T. gondii, Sarcocystis sp. and N. caninum in geese from urban parks in Curitiba, Brazil.
\end{abstract}

Keywords: Serology, IFAT, waterfowl.

\section{Resumo}

Gansos, patos, marrecos e cisnes são aves da ordem Anseriformes, encontrados em vida livre, zoológicos, parques e criados para consumo da carne. Toxoplasma gondii, Sarcocystis sp. e Neospora caninum săo protozoários capazes de infectar diversas espécies animais. Aves domésticas e silvestres podem ser hospedeiras intermediárias e servir como disseminadoras e potenciais fontes de infecção para seres humanos por meio da carne. O objetivo do estudo foi 1) realizar a soroprevalência de T. gondii, Sarcocystis sp. e N. caninum em gansos (Anser sp.) provenientes de parques públicos e de um cativeiro e 2) comparar a soroprevalência entre os locais. Foi realizada sorologia de 149 Anser sp. pelo método da reação de imunofluorescência indireta. Anticorpos para Sarcocystis sp., T. gondii e N. caninum foram encontrados em $28,18 \%, 18 \%$, e $0,67 \%$ dos animais, respectivamente; $57 \%$ dos gansos dos parques públicos e $26,53 \%$ dos animais cativos foram soropositivos para algum dos protozoários. A ocorrência de anticorpos para tais protozoários indica contaminaçáo ambiental, ressaltando a alta prevalência de anticorpos para $T$. gondii, zoonose transmitida por ingestão dos oocistos. Sugere-se uma investigação da água e medidas ambientais para reduzir a contaminação dos animais e do ambiente. Este é o primeiro trabalho que avaliou sorologicamente gansos provenientes de parques urbanos de Curitiba, Paraná para $T$. gondii, Sarcocystis sp. e N. caninum.

Palavras-chave: Sorologia, RIFI, aves aquáticas.

\footnotetext{
*Corresponding author: Aline Luiza Konell. Programa de Pós-graduação em Ciências Veterinárias, Universidade Federal do Paraná - UFPR, Rua dos Funcionários, 1540, Juvevê, CEP 80035-050, Curitiba, PR, Brasil. e-mail: mvalinekonell@gmail.com.
} 


\section{Introduction}

Geese, ducks, mallards, and swans (Order: Anseriformes, Family: Anatidae) can be found in wildlife, zoos, parks, and they can also be raised in captivity for meat production. According to Corrêa (2007), waterfowl housed in the ponds of zoos and public parks are under constant risk of exposure to the pathogens of migratory birds that visit these places during a certain period every year. Monitoring both the animals and the ecosystem in areas where guest visiting occurs frequently is suggested by Chaskda et al. (2018). Due to birds' ability to fly and their wide variety of feeds, these animals have greater exposure to parasitic infections.

Toxoplasma gondii is an obligate intracellular parasite that infects mammals and birds (MORÉ et al., 2018). Birds can be intermediate hosts for T. gondii and can become infected following the ingestion of raw meat of animals harboring tissue cysts, particularly given the cannibalistic or scavenger behavior of some carnivorous species; or after the ingestion of soil, water, or plant material contaminated with sporulated oocysts (TENTER et al., 2000; MURAO et al., 2008).

Birds are important to the biological cycle of $T$. gondii and to the epidemiology of toxoplasmosis. Poultry represent a potential risk of $T$. gondii infection to humans through the consumption of contaminated poultry products, in addition to their valuable role as sentinels since chickens are important hosts in T. gondii cycle, infecting animals through consume of their undercooked meat and for being resistant to clinical toxoplasmosis (GARCIA et al., 2000; DUBEY, 2010b). In the wild, birds can also be involved in the zoonotic cycle when used as a source of protein to feed felids and humans, and they may act as natural reservoirs for and sources of infection to other hosts and the ecosystem (VERMA et al., 2016).

Sarcocystis sp. is an obligate intracellular coccidian parasite that requires an intermediate and a definitive host (usually an herbivore and carnivore, respectively) and can affect several species of mammals and birds (El-MORSEY et al., 2015). The genus is composed of more than 100 species (some of which are zoonotic) that differ in their levels of pathogenicity, host specificity, cyst structure and location (FRANCO et al., 2018).

Neospora caninum is an obligate intracellular parasite that can have domestic and wild canids as definitive hosts (GONDIM et al., 2010). In experimental infections, it has been found that Columbiformes may be susceptible to, and may serve as intermediate hosts of N. caninum (McGUIRE et al., 1999). Although the role of birds in the life cycle of $N$. caninum is unknown, the presence of birds has been correlated with outbreaks of abortion in cattle in Italy (OTRANTO et al., 2003), France (OULD-AMROUCHE et al., 1999) and Netherlands (BARTELS et al., 1999), suggesting that birds may be involved in the sylvatic cycle of the parasite being a mechanical vector or intermediate hosts (DONAHOE et al., 2015).

Sick birds usually mask any clinical signs of diseases (DONELEY, 2016), and they can act as reservoirs for and disseminators of pathogens given their ability to fly and migrate. Epidemiological studies in birds that share spaces with humans (captivity or free life) are extremely important when monitoring diseases with zoonotic potential as they can reduce emerging diseases and assist in biodiversity conservation through assessment of the risk that the microorganisms may pose for the birds themselves (BRACONARO et al., 2015). Characterization of the microorganism and distribution of the disease are essential for formulating actions that aim to prevent infections, reducing the long-term complications and transmission of pathogens (IBRAHIM et al., 2018).

Serological surveys in Anseriformes are usually conducted in slaughterhouses (ABOULAILA et al., 2011; YANG et al., 2012; ZOU et al., 2017) or with migratory birds (PRESTRUD et al., 2007; SANDSTRÖM et al., 2013; VERMA et al., 2016); further studies are necessary and critical for assessing the prevalence of protozoan infections in other areas (MURAO et al., 2008). Serological surveys of $T$. gondii, Sarcocystis sp., and $N$. caninum in birds in Brazil are scarce, and there is no information about the seroprevalence of these protozoa in geese. Geese maintain contact with humans and migratory birds, and thus can serve as reservoir hosts and vectors of zoonotic pathogens (CORRÊA, 2007; YAN et al., 2011; CONG et al., 2012; VERMA et al., 2016).

Considering the important epidemiologic role these species may play disseminating these protozoa, the aim of this study is to determine the seroprevalence for T. gondii, Sarcocystis sp., and $N$. caninum in geese (Anser sp.) from urban parks. We also hypothesize that wild geese (from parks) are more exposed to protozoans than captive geese (kept in a conservationist institute). Therefore, the secondary aim of this study was to determine the seroprevalence of geese kept in captivity in southern Brazil and to compare the results obtained from animals from urban parks.

\section{Materials and Methods}

\section{Animals}

The study population comprised 149 geese (Anser anser and Anser cygnoides) caught between June 2017 until February 2018. One hundred from three public parks in the city of Curitiba, Brazil (52 from Barigui Park, 9 from Tingui Park and 39 from São Lourenço Park) and 49 from a conservational institute in São José dos Pinhais, which is the surrounding metropolitan area of Curitiba, Brazil.

Of the total sample, 130 geese were adults and 19 were young. The young were determined when the animal weight less than $2,5 \mathrm{~kg}$, had initial plumage and notched tips of tail feathers. The geese were captured by placing a net on the animal and submitted to individual physical examination (assessment of body condition, examination of eye, beak, oral cavity, feathers, wings and legs, palpation of the abdomen, cardiac and respiratory auscultation and search for ectoparasites). All captured animals were sampled and added to the study population. Blood samples were collected via medial metatarsal venipuncture using $5 \mathrm{~mL}$ sterile syringes with $25 \times 7 \mathrm{~mm}$ gauge needles. After sampled, a plastic numbered leg band was placed on the left leg of each animal for further evaluation of migratory behavior. This study was approved by the animal ethics committee of the Federal University of Paraná (Protocol number 125/2016) and by the Parks and Squares Committee of Curitiba City Hall. 


\section{Parks and conservationist institute}

Barigui Park (2525'34.52 "S 49 $18^{\circ} 27.03$ ” W) has an area of $1,4000.000 \mathrm{~m}^{2}$ located on the banks of the Barigui River. Flocks of geese (A. anser and $A$. cygnoides) are commonly sighted cohabiting with ducks, caracaras, capybaras, preas, agoutis, opossums, and different species of passerines. These geese feed mostly on grass and food provided by park visitors (e.g., popcorn, corn, and bread).

Tingui Park $\left(25^{\circ} 23^{\prime} 36.05^{\prime \prime S} 49^{\circ} 18^{\prime} 21.71^{\prime} \mathrm{W}\right)$ is also located on the banks of the Barigui River and has an area of $380,000 \mathrm{~m}^{2}$. Approximately 10 geese cohabit with a large diversity of birds, reptiles, and mammals and feed on grass and various foods provided by visitors.

São Lourenço Park (2523'2.400”S 49¹5'55.440”W) has an area of $204,000 \mathrm{~m}^{2}$, it is located on the banks of the Belem River and is home to flocks of up to 70 individuals of geese ( $A$. anser and A. cygnoides). Geese receive daily feeds of corn by park employees, but they also receive bread and popcorn from park visitors. A large amount of birds (raptors, ducks, galliformes, and passerines) and mammals are seen in the vicinity of the park.

The conservationist institute $\left(25^{\circ} 35^{\prime} 17.624^{\prime \prime}\right.$ S 49 $\left.10^{\prime} 49.184^{\prime \prime W}\right)$ is located in São José dos Pinhais, surrounding the metropolitan area of Curitiba, Brazil. It is home to several species of mammals and birds, including 49 domestic geese $(A$. anser). The geese are kept in two large open enclosures (approximately $3000 \mathrm{~m}^{2}$ each) containing artificial lakes, and they cohabit with ducks and swans. They have had their wings clipped and are fed on grass, commercial food, fruits, and vegetables. Due their monitored feeding and environment, they were considered as a "captivity control" in comparison to wild animals (from urban parks).

\section{Laboratory testing}

Blood samples were immediately conditioned in tubes without anticoagulant and transported at room temperature to the laboratory. Samples were centrifuged for 5 minutes at 5,000 rpm to obtain the serum and then stored at $-20^{\circ} \mathrm{C}$ until serological analysis. Detection of specific T. gondii, S. neurona and $N$. caninum antibodies were carried out by an immunofluorescent antibody test (IFAT). Slides were prepared with tachyzoites of the $N$. caninum NC-1 strain, tachyzoites of the $T$. gondii $\mathrm{RH}$ strain, and merozoites of the $S$. neurona SN37R strain with carbonate-buffered glycerin ( $\mathrm{pH}$ 9.5) and a coverslip. All the strains were from in vitro culture in Vero cells at the Laboratory of Veterinary Clinical Pathology of
Federal University of Paraná. Geese serum samples were diluted in phosphate buffered saline (PBS; $\mathrm{pH} 7.2$ ) at a concentration of 1:25 (MARTINS et al., 2011), and conjugated anti-Duck immunoglobulin (Ig)G (KPL ${ }^{\circledR}$, Milford, MA, USA) was used as a secondary antibody at 1:50 dilution. Dog sera positive for $N$. caninum and $T$. gondii were used to validate a positive control of positive geese sera, which was used for further analysis. A positive serum sample obtained from a bird of prey was used as a positive control for Sarcocystis sp. Only samples that exhibited fluorescence of the entire parasitic surface were considered to be positive (LOCATELLI-DITTRICH et al., 2006; RIBEIRO et al., 2016). Endpoint titers were determined by serial dilutions from $1: 25$ to $1: 150$.

\section{Statistical analyses}

Statistical analyses were performed using EZR 1.37 (KANDA, 2013), which is a graphical interface for $R$ commander (The $R$ Foundation for Statistical Computing, Vienna, Austria, version 3.4.4). Association between age (adult or young), collection point, and the presence of antibodies against each protozoa were analyzed using a chi-squared test. Statistical significance was set at $P<0.05$ for all analyses.

\section{Results}

Antibodies to either T. gondii, Sarcocystis sp. and/or N. caninum were detected in 70 of 149 geese (Table 1). Antibodies to Sarcocystis sp. were detected in 42 samples, T. gondii in 27 samples, and $N$. caninum in one sample. Co-infection with $T$. gondii and Sarcocystis sp. was reported in 8\% (12 of 149) of geese - one young and 11 adults.

Seropositive animals were found in all places where this study was performed. Antibodies to $N$. caninum were detected in only one animal, which was kept in captivity (conservationist institute) (Figure 1). The detection of T. gondii antibodies was significantly higher in animals from urban parks $\left(X^{2}=5.9303 ; P=0.015\right)$ than in animals from captivity, although significant differences were not observed for neither $N$. caninum $\left(X^{2}=0.1336 ; P=0.715\right)$ nor Sarcocystis sp. $\left(X^{2}=2.7932 ; P=0.095\right)$.

Serum antibodies titers ranged from 1:25 to $1: 150$. Antibodies to $T$. gondii were detected at 1:25 titer in 25 animals (all locations) and at 1:50 titer in two animals from Barigui Park. Antibodies to Sarcocystis sp. were detected at 1:25 titer in 22 animals

Table 1. Occurrence of antibodies to Toxoplasma gondii, Sarcocystis sp., and Neospora caninum and their co-infection in geese (Anser sp.) from urban parks and captivity in Curitiba and metropolitan area, Brazil.

\begin{tabular}{|c|c|c|c|c|}
\hline & \multicolumn{3}{|c|}{ Public Parks } & \multirow{2}{*}{$\begin{array}{c}\text { Captivity } \\
\text { Captivity }(n=49)\end{array}$} \\
\hline & Barigui $(n=52)$ & Tingui $(n=9)$ & Sáo Lourenço $(n=39)$ & \\
\hline T. gondii & $13(25 \%)$ & $2(22.2 \%)$ & $9(23 \%)$ & $3(6.1 \%)$ \\
\hline Sarcocystis sp. & $13(25 \%)$ & $7(77.7 \%)$ & $13(33.3 \%)$ & $9(18.3 \%)$ \\
\hline N. caninum & 0 & 0 & 0 & $1(2.04 \%)$ \\
\hline Total & $26(50 \%)$ & $9(100 \%)$ & $22(56 \%)$ & $13(26 \%)$ \\
\hline Co-infection* & 5 & 2 & 4 & 1 \\
\hline
\end{tabular}

$\mathrm{n}=$ total number of animals from each park and captivity). ${ }^{*}$ Co-infection: Seropositivity for both Toxoplasma gondii and Sarcocystis sp. 
(all locations), at 1:50 titer in 17 animals (all locations), at 1:100 titer in two animals (from captivity) and at 1:150 titer in one animal (from captivity). Antibodies to $N$. caninum were detected at 1:25 titer in one animal from captivity.

Age was not significant for the detection of $T$. gondii $\left(X^{2}=0.36151\right.$; $P=0.548), N$. caninum $\left(X^{2}=5.9761 \mathrm{e}-30 ; P=1\right)$, and Sarcocystis sp. $\left(X^{2}=0.0062 ; P=0.937\right)$ antibodies. 63 adults and seven young animals were seropositive to at least one of the protozoa (Table 2).

\section{Discussion}

The occurrence of antibodies to Sarcocystis sp. and to T. gondii was $28 \%$ and $18 \%$ of all geese, respectively. The percentage of seropositive animals for $N$. caninum was low, accounting for $0.74 \%$ of the total population.

Antibodies to Sarcocystis sp. were detected in geese from all urban parks and from captivity. Most of the geese (90\%) in

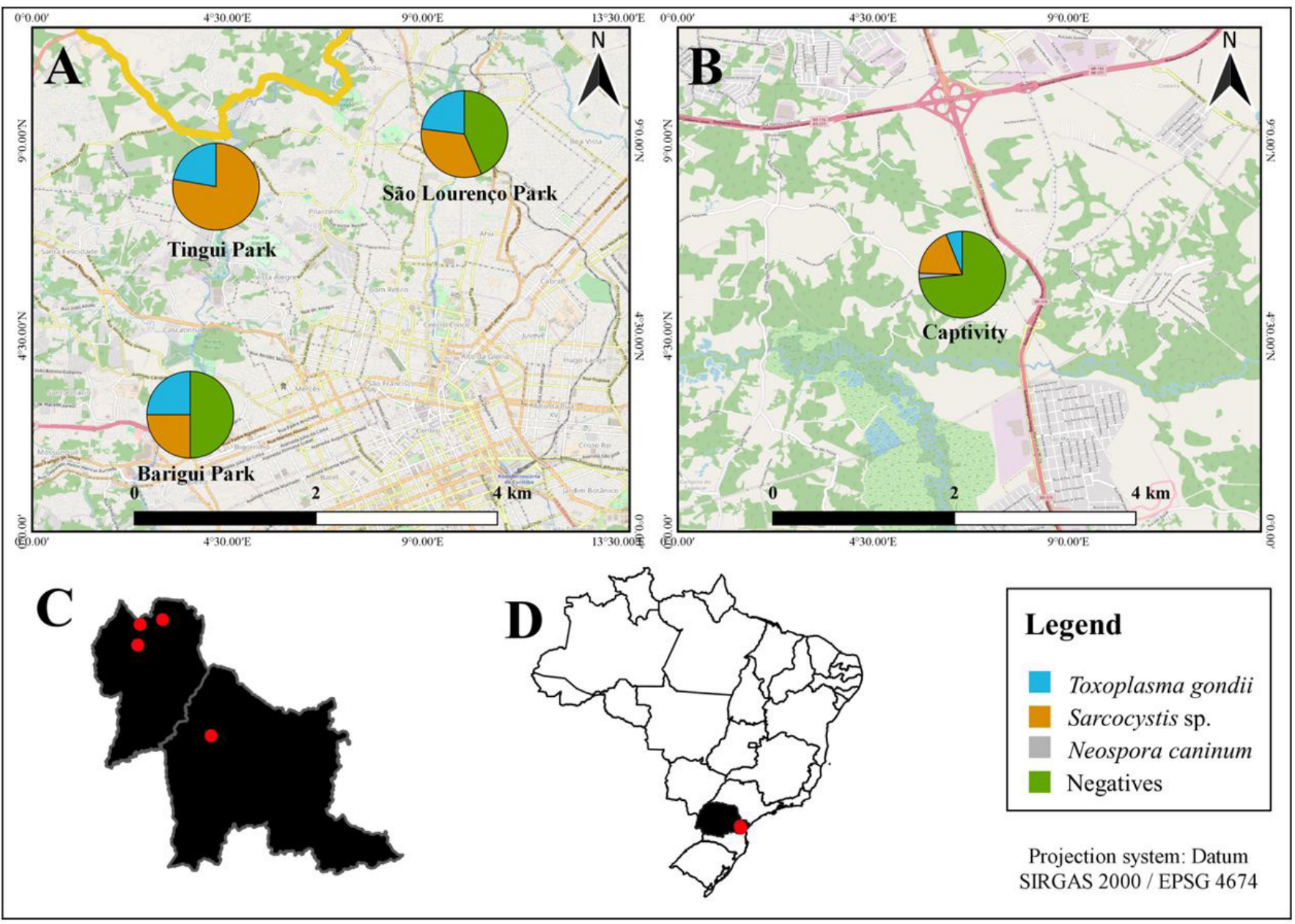

Figure 1. Map showing the location of the study area, including public parks and a breeding center in Paraná, Brazil, and the respective seroprevalence of Toxoplasma gondii, Sarcocystis sp., and Neospora caninum at each locality. (A) Location of public parks and the respective seroprevalence of Toxoplasma gondii, Sarcocystis sp., and Neospora caninum; (B) Location of the conservationist institute with seroprevalence of T. gondii, Sarcocystis sp., and N. caninum; (C) Map of Curitiba and the surrounding area, pinpointing the location of urban parks and the breeding center; (D) Map of Brazil showing the location of Paraná state and Curitiba city.

Table 2. Percentage and absolute numbers of young and adult geese seropositive to Toxoplasma gondii, Sarcocystis sp. and/or Neospora caninum, divided in parks or captivity from Curitiba and metropolitan area, Brazil.

\begin{tabular}{lcccccc}
\hline \multicolumn{1}{c}{ Protozoa } & Young & Parks & Captivity & Adult & Parks & Captivity \\
\hline T. gondii & $1(5.6 \%)$ & $1(5.6 \%)$ & 0 & $26(20 \%)$ & $23(17.6 \%)$ & $3(2.3 \%)$ \\
Sarcocystis sp. & $6(31.5 \%)$ & $6(31.5 \%)$ & 0 & $36(27.6 \%)$ & $27(20.7 \%)$ & $9(6.9 \%)$ \\
N. caninum & 0 & 0 & 0 & $1(0.76 \%)$ & 0 & $1(0.76 \%)$ \\
Total & $7(36.8 \%)$ & $7(36.8 \%)$ & 0 & $63(48.4 \%)$ & $50(38.4 \%)$ & $13(10 \%)$ \\
\hline
\end{tabular}


which antibodies to Sarcocystis sp. were detected were considered healthy at clinical examination (without any changes in evaluated parameters). Four animals seropositive to Sarcocystis sp. exhibited nonspecific clinical signs at physical examination, such as cloacal prolapse, diarrhea, and the presence of crackles on chest auscultation. Clinical signs in Sarcocystis sp. infection are more evident in old-world psittacines, and they are usually related to neurological and respiratory disorders (CRAY et al., 2005; ARCA-RUIBAL, 2016).

Antibodies to Sarcocystis sp. were detected in geese from all urban parks and from captivity. Anseriformes are intermediate hosts of at least four species of Sarcocystis: S. rileyi, S. anasi, S. albifronsi, and $S$. wobeseri (PRAKAS et al., 2014). However, there are no studies reporting the detection of antibodies to Sarcocystis sp. in geese. Antibodies to Sarcocystis sp. have been detected in psittacines either with no clinical signs or with nonspecific signs, suggesting that seroconversion did not represent an active infection in these birds but might be related to exposure to the parasite or subclinical infections (CRAY et al., 2005). Diagnosis of sarcosporidiosis is usually performed by post-mortem examinations (KUTKIENE் et al., 2010, 2012; PRAKAS et al., 2014), and ante mortem examinations are performed by muscle biopsies (CRAY et al., 2005), being therefore underdiagnosed.

Due to the wide variety of Sarcocystis species, and the wide variety of definitive and intermediate hosts (FRANCO et al., 2018; PRAKAS \& BUTKAUSKAS, 2012), it is difficult to identify the source of goose contamination. Waterfowl that inhabit and feed in shallow waters are more commonly infected than those that inhabit deeper waters (CHEN et al., 2015), suggesting that the infection occurs most commonly in shallow and marshy waters. This result indicates that the population of geese are exposed to Sarcocystis sp. in both public parks and captivity probably infected with sporocysts naturally excreted from original host.

The seroprevalence of $T$. gondii in geese in the present study was $18 \%$. There are no previous reports of serological surveys of $T$. gondii antibodies in Anser sp. in Brazil. In Europe, seroprevalence ranges from 4.8\%-43\% (BARTOVÁ et al., 2009; MAKSIMOV et al., 2011; SANDSTRÖM et al., 2013) and from 4.7\%-17\% in Asia (MURAO et al., 2008; YAN et al., 2011; YANG et al., 2012; RONG et al., 2014). Geese populations from these studies comprised wild, domestic, and hunted animals.

Several serological tests have been employed to detect antibodies to $T$. gondii in anseriformes, such as enzyme-linked immunosorbent assay (ELISA) (MURAO et al., 2008; MAKSIMOV et al., 2011; IBRAHIM et al., 2018), direct agglutination test (DAT) (PRESTRUD et al., 2007), indirect hemagglutination (IHA) (HARFOUSH \& TAHOON, 2010; RONG et al., 2014; NUNES, 2016), and modified agglutination test (MAT) (YANG et al., 2012; MANCIANTI et al., 2013; SANDSTRÖM et al., 2013; VERMA et al., 2016). However, there is still disagreement regarding the ideal method for detecting antibodies due to the variability of antigenic proteins, as well as differences in the sensitivity, and quality of commercial kits (SANTOS, 2012).

In two serological surveys of geese in Europe, IFAT was also employed: Maksimov et al. (2011) detected antibodies to T. gondii in $25.2 \%$ of samples and Bartová et al. (2009) detected them in $43 \%$ of samples. It is important to emphasize that these studies were performed on animals from production farms, which are intended for meat consumption. This information is important since T. gondii is a zoonosis, the comsumption of raw or undercooked meat is one of the main routes of infection (YAN et al., 2011).

Contamination of water by protozoa has also been acknowledged as an important source of infection. The presence of an aquatic environment is one of the few similarities featured in different studies that document seropositive animals from different environments and continents (BARTOVÁ et al., 2009). T. gondii oocysts were shown to be viable in the aquatic environment for several months (DUBEY et al., 2003; 2007); hence, surveys of waterfowl infection can serve as good indicators of water and environmental contamination (DUBEY, 2010a; WAAP et al., 2008). Infection of $T$. gondii possibly occurred due to the ingestion of sporulated oocysts in contaminated pasture and water. Oocysts are shed by definitive hosts (felines), as free-roaming cats have unconditional access to urban parks and they have also been sighted in the conservationist institute.

Waterfowls can be a source of toxoplasmosis infection to humans and domestic animals (MURAO et al., 2008), particularly in places where these animals are hunted and consumed, such as in Canada, Europe, and the United States. The presence of visible muscular cysts (macrocysts) is not common in geese, enabling the meat to be consumed without suspicion of contamination (WOBESER et al., 1981). According to park employees from the urban parks documented in this study, it is not unusual for geese to disappear from parks, which may be due to predation by animals and humans. A serological survey of T. gondii antibodies in capybaras from Tingui Park revealed the presence of antibodies to $T$. gondii in $62.5 \%$ of animals (TRUPPEL et al., 2010). In the present study, $22 \%$ of geese were seropositive for T. gondii and $77.7 \%$ were seropositive for Sarcocystis sp., endorsing the need to monitor environmental contamination in Curitiba's urban parks.

Nunes (2016) performed a serological survey of $T$. gondii antibodies in ducks (Cairina moschata) sent to a slaughterhouse in Pará, Brazil, and verified a seroprevalence rate of $16.28 \%$, similar to the results of the present study (18\%). According to Nunes (2016), the risk of infection is higher in animals raised in extensive systems, a fact that was also supported by the findings of our study, where we found seropositivity to $T$. gondii to be higher in animals from public parks.

The role of birds in the $N$. caninum cycle is still unknown. It has been suggested that they might participate as intermediate hosts, particularly since the report of an immune response to and the presence of parasite DNA in raptors and passerines (GONDIM et al., 2010; DARWICH et al., 2012; MOLINA-LOPEZ et al., 2012). Rocchigiani et al. (2017) reported seropositivity in $34.5 \%$ of ducks and mallards (Anas sp.) via IFAT in Italy, and suggested that birds that feed on pasture or water plants (like waterfowl) can ingest oocysts and contribute to the transmission of the parasite in the sylvatic cycle as a potential source of infection. In the present study, antibodies to $N$. caninum were detected in only one goose (from captivity). It is possible that the low occurrence of antibodies to $N$. caninum in this study might take place due to the low rate of seroconversion for $N$. caninum in Anser sp. or due to different types of feed. 
There was no significant difference between the age of the animals and the detection of antibodies to any of the protozoa $(P>0.05)$, however, Sandström et al. (2013) evaluated the occurrence of T. gondii in geese in the Arctic and in temperate areas and reported that seroprevalence increases with age, suggesting that these birds undergo rapid seroconversion. This author also suggests that juveniles must be sampled in greater numbers to directly link the site of infection with the environment; since the study population in the present study had few samples from young animals (13\% of total), further studies are encouraged to evaluate seroconversion in juvenile geese exposed to urban parks in Curitiba.

In conclusion, we observed that wild animals have a higher occurrence of antibodies to $T$. gondii than animals kept in captivity. Waterfowl are considered good indicators of water and environmental contamination (DUBEY et al., 2012; WAAP et al., 2008), suggesting that urban parks are more contaminated with oocysts in water and soil. Anser anser and A. cygnoydes presented with high seropositivity to $T$. gondii and Sarcocystis sp., indicating they may have been exposed to these protozoa in urban parks, and that they may serve as a potential source of infection to other animals. This is the first serological survey of T. gondii, N. caninum, and Sarcocystis sp. in geese from urban parks.

\section{Acknowledgements}

We would like to thank Dr. Cybelle Souza, Dr. Larissa Reifur, Dr. Rafael Vieira and Dr. Rogério Lange for helping with the manuscript and ANAMI Institute for financial support and assistance during sample procedures.

\section{References}

Aboulaila M, El-Bahy N, Hilali M, Yokoyama N, Igarashi I. Serodiagnosis of Toxoplasma gondii in ducks from Behera Governorate, Egypt.J Protozool Res 2011; 21: 45-49.

Arca-Ruibal B. Systemic diseases. In: Samour J. Avian Medicine. 3rd ed: St. Louis, Missouri: Elsevier; 2016. p. 359-433.

Bartels CJ, Wouda W, Schukken YH. Risk factors for Neospora caninum associated abortion storms in dairy herds in the Netherlands (1995 to 1997). Theriogenology 1999; 52(2): 247-257. http://dx.doi.org/10.1016/ S0093-691X(99)00126-0. PMid:10734392.

Bártová E, Sedlak K, Literák I. Serologic survey for toxoplasmosis in domestic birds from the Czech Republic. Avian Pathol 2009; 38(4): $317-$ 320. http://dx.doi.org/10.1080/03079450903055405. PMid:19937517.

Braconaro P, Saidenberg AB, Benites NR, Zuniga E, Silva AM, Sanches TC, et al. Detection of bacteria and fungi and assessment of the molecular aspects and resistance of Escherichia coli isolated from confiscated passerines intended for reintroduction programs. Microb Pathog 2015; 88: 65-72. http://dx.doi.org/10.1016/j.micpath.2015.08.006. PMid:26279195.

Chaskda AA, Mwansat GS, Sani D, Turshak L. Assessment of potential sources of protozoan contamination between two avian feeding guilds in a conservation area. Ostrich 2018; 89(1): 25-32. http://dx.doi.org/1 $0.2989 / 00306525.2017 .1368038$.

Chen J, Tsai Y, Wu Y. Seroprevalence of Toxoplasma gondii antibodies in wild birds in Taiwan. Res Vet Sci 2015; 102: 184-188. http://dx.doi. org/10.1016/j.rvsc.2015.08.010. PMid:26412541.
Cong W, Huang S, Zhou D, Xu M, Wu S, Yan C, et al. First report of Toxoplasma gondii infection in market-sold adult chickens, ducks and pigeons in northwest China. Parasit Vectors 2012; 5(1): 110. http://dx.doi. org/10.1186/1756-3305-5-110. PMid:22676311.

Corrêa SHR. Estudo epidemiológico de doenças infecciosas em anatídeos da Fundação Parque Zoológico de São Paulo [tese]. São Paulo: Universidade de São Paulo; 2007.

Cray C, Zielezienski-Roberts K, Bonda M, Stevenson R, Ness R, Clubb $S$, et al. Serologic diagnosis of sarcocystosis in psittacine birds: 16 cases. $J$ Avian Med Surg 2005; 19(3): 208-215. http://dx.doi.org/10.1647/10826742(2005)019[0208:SDOSIP]2.0.CO;2.

Darwich L, Cabezon O, Echeverria I, Pabón M, Marco I, Molina-López $\mathrm{R}$, et al. Presence of Toxoplasma gondii and Neospora caninum DNA in the brain of wild birds. Vet Parasitol 2012; 183(3-4): 377-381. http:// dx.doi.org/10.1016/j.vetpar.2011.07.024. PMid:21831525.

Donahoe SL, Lindsay SA, Krockenberger M, Phalen D, Slapeta J. A review of neosporosis and pathologic findings of Neospora caninum infection in wildlife. Int J Parasitol Parasites Wildl 2015; 4(2): 216-238. http://dx.doi. org/10.1016/j.ijppaw.2015.04.002. PMid:25973393.

Doneley B. The physical examination. In: Doneley B. Avian medicine and surgery in practice: companion and aviary birds. 2nd ed. Florida: CRC Press; 2016. p. 63-70. http://dx.doi.org/10.1201/b19656-4.

Dubey JP. Toxoplasmosis of animals and humans. 2nd ed. Boca Raton: CRC Press; 2010a.

Dubey JP. Toxoplasma gondii infections in chickens (Gallus domesticus): prevalence, clinical disease, diagnosis and public health significance. Zoonoses Public Health 2010b; 57(1): 60-73. http://dx.doi.org/10.1111/j.18632378.2009.01274.x. PMid:19744305.

Dubey JP, Lago EG, Gennari SM, Su C, Jones L. Toxoplasmosis in humans and animals in Brazil: high prevalence, high burden of disease, and epidemiology. Parasitology 2012; 139(11): 1375-1424. http://dx.doi. org/10.1017/S0031182012000765. PMid:22776427.

Dubey JP, Morales JA, Sundar N, Velmurugan GVV, Gonzalez-Barrientos CR, Hernandez-Mora G, et al. Isolation and genetic characterization of Toxoplasma gondii from striped dolphin (Stenella coeruleoalba) from Costa Rica. J Parasitol 2007; 93(3): 710-711. http://dx.doi.org/10.1645/ GE-1120R.1. PMid:17626370.

Dubey JP, Zarnke R, Thomas NJ, Wong SK, Bonn WV, Briggs M, et al. Toxoplasma gondii, Neospora caninum, Sarcocystis neurona, and Sarcocystis canis-like infections in marine mammals. Vet Parasitol 2003; 116(4): 275 296. http://dx.doi.org/10.1016/S0304-4017(03)00263-2. PMid:14580799.

El-Morsey A, El-Seify M, Desouky A, Abdel-Aziz M, El-Dakhly K, Kasem $\mathrm{K}$, et al. Morphologic and molecular characteristics of Sarcocystis atraii n.sp. (Apicomplexa: Sarcocystidae) infecting the common coot (Fulica atra) from Egypt. Acta Parasitol 2015; 60(4): 691-699. http://dx.doi. org/10.1515/ap-2015-0098. PMid:26408592.

Franco CD, Schnittger L, Florin-Christensen M. Sarcocystis. In: FlorinChristensen M, Schnittger L. Parasitic protozoa of farm animals and pets. Switzerland: Springer; 2018. p. 103-124. http://dx.doi.org/10.1007/9783-319-70132-5_4.

Garcia JL, Navarro IT, Ogawa L, Marana ERM. Soroprevalência do Toxoplasma gondii em galinhas (Gallus gallus domesticus) de criaçôes domésticas, oriundas de propriedades rurais do Norte do Paraná, Brasil. Cienc Rural 2000; 30(1): 123-127. http://dx.doi.org/10.1590/S010384782000000100020 
Gondim LSQ, Abe-Sandes K, Uzêda RS, Silva MSA, Santos SL, Mota RA, et al. Toxoplasma gondii and Neospora caninum in sparrows (Passer domesticus) in the northeast of Brazil. Vet Parasitol 2010; 168(1-2): 121124. http://dx.doi.org/10.1016/j.vetpar.2009.09.055. PMid:19879051.

Harfoush M, Tahoon A. Seroprevalence of Toxoplasma gondii antibodies in domestic ducks, free-range chickens, turkeys and rabbits in Kafr ElSheikh Governorate, Egypt. J Egypt Soc Parasitol 2010; 40(2): 295-302. PMid:21246937.

Ibrahim HM, Osman GY, Mohamed AH, Al-Selwi AGM, Nishikawa Y, Abdel-Ghaffar A. Toxoplasma gondii: Prevalence of natural infection in pigeons and ducks from middle and upper Egypt using serological, histopathological, and immunohistochemical diagnostic methods. Vet Parasitol Reg Stud Rep 2018; 13: 45-49. http://dx.doi.org/10.1016/j. vprsr.2018.04.002. PMid:31014887.

Kanda Y. Investigation of the freely available easy-to-use software 'EZR' for medical statistics. Bone Marrow Transplant 2013; 48(3): 452-458. http://dx.doi.org/10.1038/bmt.2012.244. PMid:23208313.

Kutkienè L, Prakas P, Sruoga A, Butkauskas D. The mallard duck (Anas platyrhynchos) as intermediate host for Sarcocystis wobeseri sp. nov. from the Barnacle goose (Branta leucopsis). Parasitol Res 2010; 107(4): 879888. http://dx.doi.org/10.1007/s00436-010-1945-4. PMid:20567986.

Kutkienè L, Prakas P, Sruoga A, Butkauskas D. Description of Sarcocystis anasi sp. nov. and Sarcocystis albifronsi sp. nov. in birds of the order Anseriformes. Parasitol Res 2012; 110(2): 1043-1046. http://dx.doi. org/10.1007/s00436-011-2588-9. PMid:21845412.

Locatelli-Dittrich R, Dittrich JR, Richartz RR, Gasino Joineau ME, Antunes J, Pinckney RD, et al. Investigation of Neospora sp. and Toxoplasma gondii antibodies in mares and in precolostral foals from Parana State, Southern Brazil. Vet Parasitol 2006; 135(3-4): 215-221. http://dx.doi. org/10.1016/j.vetpar.2005.10.010. PMid:16289863.

Maksimov P, Buschtöns S, Herrmann DC, Conraths FJ, Görlich K, Tenter AM, et al. Serological survey and risk factors for Toxoplasma gondii in domestic ducks and geese in Lower Saxony, Germany. Vet Parasitol 2011; 182(2-4): 140-149. http://dx.doi.org/10.1016/j.vetpar.2011.05.049. PMid:21719198.

Mancianti F, Nardoni S, Mugnaini L, Poli A. Toxoplasma gondii in waterfowl: the first detection of this parasite in Anas crecca and Anas clypeata from Italy. J Parasitol 2013; 99(3): 561-563. http://dx.doi. org/10.1645/12-34.1. PMid:23145510.

Martins J, Kwok OCH, Dubey JP. Seroprevalence of Neospora caninum in free-range chickens (Gallus domesticus) from the Americas. Vet Parasitol 2011; 182(2-4):349-351. http://dx.doi.org/10.1016/j.vetpar.2011.05.023. PMid:21676546.

McGuire AM, McAllister M, Wills RA, Tranas JD. Experimental inoculation of domestic pigeons (Columbia livia) and zebra finches (Poephila guttata) with Neospora caninum tachyzoites. Int J Parasitol 1999; 29(10): 1525-1529. http://dx.doi.org/10.1016/S0020-7519(99)00103-4. PMid:10608438.

Molina-López R, Cabezón O, Pabón M, Darwich L, Obón E, LopezGatius F, et al. High seroprevalence of Toxoplasma gondii and Neospora caninum in the Common raven (Corvus corax) in the Northeast of Spain. Res Vet Sci 2012; 93(1): 300-302. http://dx.doi.org/10.1016/j. rvsc.2011.05.011. PMid:21645913.

Moré G, Venturini MC, Pardini L, Unzaga JM. Toxoplasma. In: FlorinChristensen M, Schnittger L. Parasitic protozoa of farm animals and pets.
Switzerland: Springer; 2018. p. 149-168. http://dx.doi.org/10.1007/9783-319-70132-5_6.

Murao T, Omata Y, Kano R, Murata S, Okada T, Konnai S, et al. Serological survey of Toxoplasma gondii in wild waterfowl in Chukotka, Kamchatka, Russia and Hokkaido, Japan. J Parasitol 2008; 94(4): 830-833. http:// dx.doi.org/10.1645/GE-1434.1. PMid:18576786.

Nunes GL. Soroprevalência da infecção pelo T. gondii em patos de corte em feiras livres no município de Belém-PA [tese]. Belém: Universidade do Estado do Pará; 2016.

Otranto D, Llazari A, Testini G, Traversa D, Frangipane di Regalbono A, Badan M, et al. Seroprevalence and associated risk factors of neosporosis in beef and dairy cattle in Italy. Vet Parasitol 2003; 118(1-2): 7-18.

Ould-Amrouche A, Klein F, Osdoit C, Mohammed HO, Touratier A, Sanaa $\mathrm{M}$, et al. Estimation of Neospora caninum seroprevalence in dairy cattle from Normandy, France. Vet Res 1999; 30(5): 531-538. PMid:10543387.

Prakas P, Butkauskas D. Protozoan parasites from genus Sarcocystis and their investigations in Lithuania. Ekologija (Liet Moksl Akad) 2012; 58(1): 45-58. http://dx.doi.org/10.6001/ekologija.v58i1.2349.

Prakas P, Oksanen A, Butkauskas D, Sruoga A, Kutkiene L, Svazas $S$, et al. Identification and Intraspecific Genetic Diversity of Sarcocystis rileyi from Ducks, Anas spp., in Lithuania and Finland. J Parasitol 2014; 100(5): 657-661. http://dx.doi.org/10.1645/13-395.1. PMid:24766223.

Prestrud KW, Asbakk KA, Fuglei E, Mork T, Stien A, Ropstad E, et al. Serosurvey for Toxoplasma gondii in arctic foxes and possible sources of infection in the high Arctic of Svalbard. Vet Parasitol 2007; 150(1-2): 6-12. http://dx.doi.org/10.1016/j.vetpar.2007.09.006. PMid:17950534.

Ribeiro MJ, Rosa MH, Bruhn FR, Garcia AM, Rocha CM, Guimarães AM. Seroepidemiology of Sarcocystis neurona, Toxoplasma gondii and Neospora spp. among horses in the south of the state of Minas Gerais, Brazil. Rev Bras Parasitol Vet 2016; 25(2): 142-150. http://dx.doi. org/10.1590/S1984-29612016029. PMid:27334814.

Rocchigiani G, Poli A, Nardoni S, Papini R, Mancianti F. Neospora caninum in wild waterfowl: occurrence of parasite DNA and low antibody titers. J Parasitol 2017; 103(1): 142-145. http://dx.doi.org/10.1645/16-34. PMid:27805842.

Rong G, Zhou H, Hou G, Zhao J, Xu T, Guan S. Seroprevalence, risk factors and genotyping of Toxoplasma gondii in domestic geese (Anser domestica) in tropical China. Parasit Vectors 2014; 7: 459. PMid:25274416.

Sandström CAM, Buma AGJ, Hoye BJ, Prop J, van der Jeugd H, Voslamber $B$, et al. Latitudinal variability in the seroprevalence of antibodies against Toxoplasma gondii in non-migrant and Arctic migratory geese. Vet Parasitol 2013; 194(1): 9-15. http://dx.doi.org/10.1016/j.vetpar.2012.12.027. PMid:23339847.

Santos MCF. Frequência da infecção por Toxoplasma gondii em galinhas caipira e frangos de corte em regiöes dos estados do Rio Grande do Norte e Paraíba [dissertação]. Natal: Universidade Federal do Rio Grande do Norte; 2012.

Tenter A, Heckeroth AR, Weiss LM. Toxoplasma gondii: from animals to humans. Int J Parasitol 2000; 30(12-13): 1217-1258. http://dx.doi. org/10.1016/S0020-7519(00)00124-7. PMid:11113252.

Truppel JH, Reifur L, Montiani-Ferreira F, Lange RR, Castro Vilani RG, Gennari SM, et al. Toxoplasma gondii in Capybara (Hydrochaeris hydrochaeris) antibodies and DNA detected by IFAT and PCR. Parasitol Res 2010; 107(1): 141-146. http://dx.doi.org/10.1007/s00436-0101848-4. PMid:20445992. 
Verma SK, Calero-Bernal R, Cerqueira-Cézar CK, Kwok OC, Dudley $\mathrm{M}$, Jiang $\mathrm{T}$, et al. Toxoplasmosis in geese and detection of two new atypical Toxoplasma gondii strains from naturally infected Canada geese (Branta canadensis). Parasitol Res 2016; 115(5): 1767-1772. http://dx.doi. org/10.1007/s00436-016-4914-8. PMid:26796021.

Waap H, Vilares A, Rebelo E, Gomes E, Angelo H. Epidemiological and genetic characterization of Toxoplasma gondii in urban pigeons from the area of Lisbon (Portugal). Vet Parasitol 2008; 157(3-4): 306-309. http:// dx.doi.org/10.1016/j.vetpar.2008.07.017. PMid:18722717.

Wobeser G, Leighton FA, Cawthorn RJ. Occurrence of Sarcocystis Lankester, 1882, in wild geese in Saskatchewan. Can J Zool 1981; 59(8): 1621-1624. http://dx.doi.org/10.1139/z81-224.
Yan C, Yue CL, Zhang H, Yin CC, He Y, Yuan ZG, et al. Serological survey of Toxoplasma gondii infection in the domestic goose (Anser domestica) in southern China. Zoonoses Public Health 2011; 58(4): 299-302. http:// dx.doi.org/10.1111/j.1863-2378.2010.01349.x. PMid:20707861.

Yang N, Mu M, Li H, Long M, He J. Seroprevalence of Toxoplasma gondii infection in slaughtered chickens, ducks, and geese in Shenyang, northeastern China. Parasit Vectors 2012; 5(1): 237. http://dx.doi. org/10.1186/1756-3305-5-237. PMid:23078787.

Zou Y, Nie L, Zhang N, Zou F, Zhu X, Cong W. First genetic characterization of Toxoplasma gondii infection in poultry meat intended for human consumption in eastern China. Infect Genet Evol 2017; 55: 172-174. http://dx.doi.org/10.1016/j.meegid.2017.08.022. PMid:28842355. 